\title{
Theories of Legal Relations
}

By Emmanuel Jeuland, professor at the Sorbonne Law School.

Key Words: analogy, autonomy, coordination, emotion, equality, impartiality, interdependence, legal relation, management, narrative, substitution, symbol, third-party.

\section{Introduction}

In physics, philosophy and biology, a relational theory (or relationism) is a framework within which to understand the reality in such a way that the positions of objects will only have relevance if connected to other objects. Space does not exist independently of objects in relation. In social sciences, a social network theory is now applied to political, sociology and so on. However, human relations are not simple factual connections where language and symbols are at stake. Human relations are legal relations set for a specific period of time; failing this, they are mere contacts.

Several recent authors have a relationist or relational approach to law: in particular M-J. Falcon y Tella, J. Nedelsky, A. Somek, G. Pavlakos and M. Novak. They are not unconnected with what could be called a relational turn, linked to an emotional turn, and even to a narrative turn. The American journalist Goleman has written books on relational intelligence 
and emotional intelligence. Such relational-processual philosophy, developed based on Whitehead, has inspired scientists to think about the transformations of our conception of the world, especially physics, which increasingly appears like constituting infinitesimal strings rather than particles. Relational approaches in the field of ethics, art, and management are close to interactionist approaches in sociology and psychology. These movements are undoubtedly linked to the discoveries of neurosciences and in particular mirror neurons. Humans are not closed or isolated from each other; they are connected and can feel each other's suffering.

How may relationism be specifically translated into law? Several authors in recent years have stressed, in various traditions, the need to take into account legal relationships and not just institutions or norms. J. Nedelsky, in Canada, has a common law approach where A. Somek, in Austria, has a Kantian and critical approach to such common law; M-J. Falcon y Tella using Mr Reale's three-dimensional theories of law based on the triptych of fact, value and norm distinguishes three possible perspectives in law: the theory of the norm, the theory of the legal order and the theory of legal relationship.

These authors do not constitute a school of legal thought if we understand this as a set of authors linked together, a certain transmission over several generations or even a place of transmission, such as the Brussels School of Legal Theory, which has been established for more than 120 years. Can we say, on the other hand, that there is a theory of law called Legal Relationism or Law and Relation?

The relational theory of law is neither a mere consideration of human relations or social ties in law nor about looking at human relationships from a legal perspective. This theory places 
first, in judicial reasoning, the concept of a legal relationship, which is not only the legal form of the human relationship. It is important from the outset to avoid any misunderstanding. In a strong sense, the legal relationship is the human relationship itself because there is no human relationship without a legal relationship. Humans are neotenies (born prematurely): they must relearn everything (to walk, talk, swim, etc.) they knew when they were born. They have to recreate relationships as well, in order to live in peace with other human beings, where animals have biological relationships bordered by natural laws. The human bond can only be durable if it is symbolized and therefore legal; in other words, a symbolized and durable human bond constitutes the definition of the legal bond. The social link, as an encompassing concept, therefore does not exist other than as a set of legal links. If we renounce this starting point, the legal relationship is a pure social link, i.e. a social effect of objective law and becomes secondary. If we equate the relationship of law with a right, we also leave the relational theory for Grotius' legal humanism. As soon as we are interested in interactions conceived as objects of observation, we are in a form of realism or pragmatism. These other currents of legal theory have their legitimacy, but do not seem to be able to constitute a theory of legal relations. We can also distinguish three types of legal relationship (a term used here in a generic sense): the personal legal relationships (filiation, marital relationship, nationality, procedural relationship), the legal relationships used to get ownership (obligation, contractual relationship) and the legal relationships close to factual relationships (business relations, commercial relations, digital relations).

There are at least two versions of the relational theory of law that complement each other, one which is dogmatic (Savigny, Somek) while the other one which is axiological (Nedelsky). The Law and Relationship movement might be the simultaneous consideration of those two versions. 
Why should this be an appropriate theory today? It may help to think about the confrontations between law and technical networks, take into account a certain decline of institutions, the rise of non-legal norms (technical standards), a better knowledge of emotions with neuroscience and even literature as a place of synthesis of emotions and reason. It also makes it possible to criticize the management of justice and law based on an individualist approach as a human right approach. After showing that two distinct currents of relationism have emerged (I), it will appear that a unity is possible (II).

\section{I.- Two distinct relational trends in law.}

Legal theorists can be classified according to the concept of legal relationship in four categories:

1st category: those who criticize or ignore the notion of a legal relationship as a legal relationship between people. Duguit favoured objective law over subjective law; Hauriou gave prevalence to the institution; Kelsen dealt with the link between norms, as well as, in a certain way, Ihering and those authors who, following him, considered that the legal relationship is nothing more than another way of presenting rights. Hohfeld transformed legal relationships into a logical relationship between rights, obligations, freedoms and powers. Hart might also have denied the existence of legal relationships, even though his concept of ascription (concerning liability) shows that he considered law as not only a matter of primary and secondary norms. 
Paradoxically, in the category of authors who chose to ignore the concept of legal relationships there are those who refer to interactions. Fuller, in his paper on the formation of law from interactions between people, was very close to considering that legal relationships between people logically preceded the norm. However, for Fuller, the interaction was factual and not legal. In the Brussels School too, the observation of interactions makes it possible to detect binding effects and is part of the law in the overall sense of the term. However, it is a way of overwriting the legal relationship under the factual one. The theory of constraints of the realistic approach to interpretation (Nanterre School of Law, led by M. Troper) carries out the same operation when it claims to see the emergence of interpretations in the representations made by the courts (especially the superior ones) of the impact their decisions will have.

2nd category: those who use the concept of legal relationship without making it the basis of an overall theory. Gény underlined the importance of the concept of a legal relationship in a footnote. Villey defined ius as a legal relationship operating the distribution of property and honours, but had a general Aristotelian jusnaturalist approach and not a purely relational one. Internationalists, since Savigny, have located legal relationships while theoretically referring to Santi Romano or Kelsen. The concept then becomes part of legal dogmatic without being questioned.

3rd category: those who make it a theory within a dogmatic approach of law. Such authors, certainly isolated, may be found in every great tradition. Within the German-speaking sphere, some thinkers, since Savigny, such as Achterberg in 1982 have referred to the set of legal relationships as a definition of the legal order. Alexander Somek, in Austria in 2017, stressed the importance of legal relationships, which allows everyone to put themselves in each other's 
shoes, particularly during a trial. He has, as G. Pavlakos, a Kantian approach based on the reasonable, free and capable agent. In Italy, Bernardino Cicala, around 1950, stated that the relationship of law was a link between a person and a norm, and that made him a normativist. At the same period of time, Alessandro Levi presented a philosophy of law based on the legal relationship referring to German authors since Savigny. However, Bobbio declared that this approach atomized society and that the norm preceded logically any legal relationship. In an Italian textbook on legal theory published in 2006 by Catania, three theoretical currents were retained: normativism, institutionalism and the theory based on legal relationships. In Spain, Ferrer Arellano wrote an essay on legal relationships in 1963 in a jusnaturalist approach inspired by Thomas Aquinas. M-J. Falcon y Tella in 2010 identified three legal perspectives from Reale's three-dimensional approaches to law, but Reale's research focused on the structure of law (value, norm, fact), while Falcon y Tella sought the content of law from three perspectives: the norm, the legal order and the legal relationship including rights. However, its developments on legal relationships are rather brief and dry. A Slavic current also exists, but is difficult to analyse today: for example, Zirk-Sadowski in Poland in the 20th century and Korkunov, translated into French, who lived in Russia at the end of the 19th century, both referred to the concept of legal relationships. Korkunov, in particular, criticized the subjective and voluntarist approach of legal relationships as developed in Germany, which led to the merging of this notion and in parallel, with that of rights. The concept is used today in Russia to define contracts. In Portugal, D. de Andrade and Carvalho can also be mentioned. The latter criticizes the disembodied nature of Savigny's theory of legal relationships. Nowadays, the concept of legal relationships is used by Brazilian proceduralists to explain the new trends of procedural law. 
4th category: some philosophers of law insist on human relationships. In North America, legal feminists, such as J. Nedelsky, have not yet established a regime of legal relationships, but rather a three-step approach and method: what legal relationships are at stakes, which interests and values are involved and what promotes people's autonomy in the relationship and their interdependence. Other contemporary philosophers in this sense can be mentioned, such as Laurent de Sutter in Belgium and, in an unexpected way, Foucault (he actually called for the emergence of a relational law in an interview). This meant for him a system of law where all relationships would be recognized.

It is more complicated to categorize authors outside the Western tradition, where law is not always clearly distinguished from religion or morality, but this is not entirely impossible. For example, the Egyptian goddess of justice, Maât, called for relationships to be taken into account in finding legal solutions. In traditional legal systems, there is a search for social harmony and a consideration of relationships. This is particularly the case with Giri's concept in Japan, which refers to the idea of social duty in the context of human relations (Benedict).

It is curious to observe that all these theoretical attempts of legal relationism have rather failed in the Western world, perhaps because legal relationships remain invisible and somewhat elusive (and may therefore be the target of nominalist criticism), perhaps also because they confuse law with fact, or even worse are stuck between law and fact. Despite these failures and diversity, it does not seem impossible to identify a unified theory of legal relationism.

\section{II - A possibility of a unified theory of legal relationships.}


J. Nedelsky does not have a dogmatic approach but rather a pragmatic one. A. Somek is more dogmatic (as G. Pavlakos); he takes values somewhat into account, but is rather critical of common law, which mixes law and ethics. By taking the best of each of these authors, we can present a unified theory (A) around a common regime (B).

\section{A.- The possibility of a single theory.}

It is possible to articulate philosophers of law such as J. Nedelsky, M. Nussbaum and more Continental theorists of law, as, for all these authors, a human relationship is not a purely biological relationship, but is culturally constructed by law. This raises the question of the legality in the approach. It can be argued that, for this movement, we can speak of law as soon as we are in the presence of a legal relationship. It is still necessary to define the notion of legal relationship.

We need eight elements in order to speak of a legal relationship: 4 participants, a fair distance expressing the participants' independence and autonomy, a form (or symbolization), a direction in the form of a norm, participants' rights and duties, an object, a reason for being in the relationship and possible permutations (substitution, succession, representation), as we can legally or in thought put ourselves in the other's place.

1 - Four participants: the legal relationship is created under the aegis of a third-party having authority, be it a State, an arbitrator, a notary-solicitor or another person such as a bailiff; it also requires a 4th agent in a broad function of witness, as an expert, a clerk, etc. This is the 
usual pattern but two parties only may already constitute a legal relationship if it is symbolized (e. g. Laban and Jacob in the Bible making a pile of stones). According to G. Pavlakos, two parties create a new situation, which is a kind of a third entity (the two of them is more than the two parties alone).

The two "parties" may not necessarily be human beings; in my view, one of them could be a natural being without being a legal person, the theory of the legal person being relatively recent and not having prevented at least ten centuries of litigation against animals. In such a case, this is a half legal-symbolic link being symbolic only for the human person who has duties towards natural beings who only have interests (more than rights).

2 - A fair distance: the parties must be autonomous or strive for autonomy in interdependence. The legal relationship is a fair distance between autonomous parties and other participants, i.e. a space or a gap, which excludes relations without a term or without the possibility of leaving it (e.g. slavery).

3 - A symbolization (a solemn or probationary form). In Greek antiquity, a piece of wood could be cut in half (this is the origin of the word symbol), and was also used as proof of the relationship. In addition, a stone mound served as a symbol for the contract concluded between Laban and Jacob. This symbol made the bond durable. Consequently, the symbolic device of the legal relationship is not the mere form of the human relationship, but what constitutes it. Nowadays, paper contracts have replaced clods of land to symbolize the sale of a land, but there are still symbolic traces today in real-estate sales, such as the handing over of the keys, the signature before a notary-solicitor, or even today in notary-solicitor offices. 
4 - A direction given to the relationship (the norm): the symbolic device also implies a direction given to this fair distance between the parties, which the parties can give themselves. This given direction is the rule or norm, what drives the parties, what they are going towards, for example the performance of an obligation. There is always a procedural aspect in the legal relationship since it develops over time. This standard is set taking into account values, mainly the search for autonomy in interdependence, but also the independence of the third party who has authority. Normativists might object that there must be a standard that precedes the legal relationship. If, at the beginning of the Middle Ages, before the building of courthouses, a dispute was settled in an area separate from the rest of the village, a standard was needed to say that it was necessary to go to that area. Certainly, but one could also say that the two people who were fighting were separated, put at a distance in a neutral place under the aegis of a respected person with witnesses where they started talking. Is that a standard or a simple human reaction? When human beings first used this specific area, there was no standard yet. On the contrary, the norm as a direction was established within the symbolic device, indicating where to go and allowing a comparison with the evolution of the relationship over time. Institutionalists, such as Hauriou, might object that man is still in society. If there is a third party, it is because there is an institution. If we consider, from a legal theory perspective, that groups precede legal norms and relationships, we accept to have a historical but not a logical approach. At some point, human beings have to organize this group and start with a few people. A friendship relationship is often part of a legal network (same school, same institution, same profession, etc.) and as such is based on legal relationships. The norm may also come from outside a legal relationship but formed in another legal relationship (e.g. parliamentary procedure leading to a statute). Even from outside, the standard is recreated in the legal relationship to be interpreted (Fuller). 
5 - Rights, duties, powers. The direction (standard) that the parties give themselves and/or are given to them for their interpretation includes rights allowing them to claim from the other the duties to do something. The third party having the authority has the power to modify the parties' rights and duties (e. g. jurisdictional power).

6 - Purpose. A legal relationship has a purpose: goods in a contractual sales relationship, a service in the provision of a service, education in the filiation relationship, legal proceedings in the litigation relationship, public service in the citizenship relationship. A legal relationship that has an illegal object (e.g. sale of drugs) is null and void.

7 - Cause. The legal relationship has a raison d'être that may or may not be lawful. Thus, a false marriage to obtain a residence permit may be annulled. A legal claim without a factual or legal basis is, in principle, void.

8 - Legal operations between parties. The legal relationship is a dynamic device in motion with operations concerning the parties such as succession, substitution, permutation and representation. These operations are part of legality criteria, as it is in the essence of the legal relationship for a party to be able to leave it.

These different elements make it possible to identify a legal relationship as a legal-symbolic mechanism with its own regime.

\section{B. The legal relationship regime.}


The particularities of any legal theory can be summarized in ten points. Indeed, any theory of law includes a theory of sources, interpretation, legal order and effectiveness as well as an approach to the distinction between law and morality, between "sein" and "sollen" ("is" and "ought"); it also includes a central principle, a definition of law, a critical aspect and a favoured mode of access to the world (sensation, reason, emotion or intuition, see Novak).

1 - The theory of sources. There is a theory of the sources of law in the relational approach, with a source that might actually be an internal or an external one. Parties can create their standards as in Fuller's interactionism. The standard can also be provided by the third party having authority (a judge or an arbitrator) or by more abstract and general external rules applicable to a set of legal relationships (a statute). Even in that case, the standard is the result of a discussion process, such as parliamentary procedures. There is therefore no rigid hierarchy of norms, but upward and downward circles in the scale of norms. The sources of law are circular in relationism (Somek).

2 - The theory of interpretation. Relationism favours the interpretation of a norm between the parties themselves with the help of a third party that has authority. J. Nedelsky's test can be used to interpret a norm: what are the legal relationships involved? What are the interests and values involved? What is the interpretation that maximizes the autonomy of the parties in their interdependence? Interpretation by analogy is also privileged because it is linked to symbolization (in the psychological process of symbolization, one distressing event is symbolized by another thing, which in turn becomes distressing and is replaced by something else). Symbolization (Jeuland, 2016) allows a representation of an elusive human relationship by something else that can be touched with the finger (the object broken in half called symbolon in antic Greece or, nowadays, the written contract). 
If we accept the existence of a legal concept of relation as comprising eight elements as described above, then we can make the following reasoning. In a trial, parties are under the aegis of the judge by a procedural bond. The judge is bound to other members of the judiciary by judicial ties: he can give orders to a clerk or an expert. The judge, as a civil servant, is placed in a hierarchy involving a president and his/her court hierarchically lower than the Court of Appeal and the Supreme Court (which often has a supervisory power). Consequently, a judge has legal constraints in his/her interpretation, which depends on the rights and obligations s/he has in procedural and judicial relationships.

3 - Legal orders can be seen as a set of legal relationships, legal norms (as they arise from a legal relationship), legal persons or more broadly legal entities as nodes of relationships, and rights (as they imply a relational test of Nedelskian type already mentioned). The State legal order is not closed as it is in relation to other more general orders (EU law, international law), with legal relations transcending legal orders (e. g. a mixed marriage, a group of multinational companies, NGOs, sports federations, etc.). G. Pavlakos suggested (Lucern IVR Colloquium, July 2019) that the relationist approach is a monism accepting a dose of pluralism since legal orders are all connected through legal relationships and eventually form a single global order.

4 - The distinction between morality and law. In principle, the ethical question is about the future solution to a current choice: is one in favour of euthanasia and surrogate mother? The answer may be social or individual. This becomes law when the solution is chosen within the political legal relationships (especially of Parliament) or when it is part of particular legal relationships (family and medical relationships). Law contrary to ethic operates with a retroactive loop: the rule exists in advance and can be applied to a situation relative to the end 
of life or procreation. There is therefore a clear distinction between law and morality in the relational approach. However, morality plays a role upstream of law, at the political level. There is, moreover, a minimum of natural principles in relationism. These are the principle of seeking autonomy in interdependence (Nedelsky) and the principle of independence and impartiality of the third party who has authority.

5 - The main principle of relationism. Amongst legal relationships, there is no real hierarchy (except with Ferrer Arellano) but potential substitutions of parties. We can speak of a substitution principle aimed at refining autonomy in relationships (thus taking into account minimum values), instead of the traditional principle of equality between separate individuals in a liberal model. A new version of equality can be envisaged: relational equality, so that everyone has the same opportunity to empower themselves in interdependence to refine the solution e.g. from the filiation bond to the marital bond; from an administrative link with schoolteachers to a subordinate contract with employers. Substitution never implies definitive replacement except when a person dies (e.g inheritance).

6 - The relational approach of law combines emotions, sensations, reason and intuition (Novak). Relationism requires that the field of reason be somewhat broadened and that other modes of access to the world, the five senses, intuition and emotions, be taken into consideration without psychologizing the legal relationship (thus, the solution of the dispute does not depend, for the most part, on the judge's personality and mood). Emotions are contained and used by procedural relationships to help, for example, to build a judicial decision. 
7 - Relationism position regarding the distinction between "sein" and "sollen" ("is" and “ought”). J-Y. Chérot (a French scholar, Quebec City Conference, 2018) states that the relationship programme cannot really prosper because it is based on confusion between law and fact. However, the Nanterre theory of constraints (Troper) fails to distinguish the different facts that lead to the judgment, thus making it difficult to escape psychologization. In relational theory, the procedural relationship is the place where the fact is transformed into law. The relational theory is at the intersection of fact and law, in this continuum where the taking of evidence and the legal characterization of facts constitute the legal moment. This is R. Sève's answer to the strict opposition of fact and law (e.g. an umbrella: there is no causality between the rain and taking an umbrella, but family and professional relations can lead to taking an umbrella, so it is possible to say that relationships are the places where fact becomes law).

8 - The definition of law: a set of legal relationships as symbolic spaces between parties under the aegis of a third party (often involving a fourth person), involving legal norms as they arise and are interpreted in legal relationships, legal persons or more broadly legal entities as nodes of relationships and rights as they involve a Nedelskian type relational test (see above). Validity is not a central issue in relationism (contrary to normativism) since, for example, a custom has not to be acknowledged by a court to be valid law; a custom belongs to law as soon as it is acknowledged by the parties in a relationship giving them a direction.

9 - Efficiency. Relationism is based on the weak strength of symbolic mechanisms to enable people to empower themselves in interdependence without being forced to do so by sanctions and sometimes illusory technical constraints. Enforcement can never be completely forced; it requires the parties' consent. 
10 - Criticisms. Relationism criticizes the individualistic approach based on noninterdependent isolates leading to libertarianism and disrupting inequality (however, G. Pavlakos and A. Somek based their relationist approach on a free, reasonable and independent individual). This method also criticizes the collectivist and institutionalist approaches based on the group crushing the individual and destroying inter-individual ties. It criticizes normativism as reductive and the sein/sollen (is/ought) distinction as too radical as there is a continuum from fact to law through legal interaction using the judicial method (allegation of facts, evidence, characterization of facts, interpretation, argumentation, evaluation). This theory criticizes the managerial (and economic) approach to justice as being based on competitive individualism and refusing to favour relational coordination between courts and lawyers.

\section{Conclusion}

The relational theory of law gives rise to work in many countries (Canada, England, Spain, Austria, France, etc.) and bases law on symbolically structured human relations and not primarily on the State or the individual. This theory may be a good candidate (probably with others) to organize mutual assistance, coordination, legal imagination and hospitality in a time of potential collapse due to climate change. It takes into account emotions, reason, intuition and imagination in the judge's work. It is necessary to ensure legal networking that generates human relations in which each person can achieve the greatest possible autonomy in interdependence. Digital network cannot replace such a symbolic net, but the infinite fragmentation of the former can be overcome by the cultural meshes of the latter. 


\section{References:}

N. ACHTERBERG, Die Rechtsordnung als Rechtsverhältnisordnung, Duncker and Humblot, Berlin (1982).

T.W. ARNOLD, "Law as symbolism", in V. Aubert, Sociology of law, Baltimore, Maryland, Penguins Books, p. 46-51, (1969).

J. ASSMANN, Ma'at: Gerechtigkeit und Unsterblichkeit im Alten Ägypten (in German). C.H. Beck Verlag ; (2010), Ma'at, L’Egypte Pharaonique et l'idée de justice sociale, MdV editor (1990).

R. BENEDICT, The Chrysanthemum and the Sword, new ed., Mariner Books, 2006. (1946).

N. BOBBIO, "Teoria generale del diritto e teoria del rapporto giuridico", in Studi sulla teoria generale del diritto, Turin, p. 53 ff. (1955). 
R. BRUGEILLES, "Le droit et l'obligation ou le rapport juridique", Revue Trimestrielle de Droit Civil, Paris, p.293-325 (1900),

J. BRUNNÉE and T. TOOPE, Legitimacy and legality in International Law, an Interactional Account, Cambridge University Press (2010).

A. CATANIA, Manuale di teoria generale del diritto, GLF editori Laterza, Roma-Bari, (2006).

B. CICALA, Il rapporto giuridico, 3rd ed. 1940, Milan (1959).

O. DE CARVALHO, A teoria geral da relaçao juridica, seu sentido e limites, Coimbra, Centelha (1981).

A. DOMINGUES ANDRADE, Teoria Geral da Relação Juridica, Vol. I, Ed. Alemedina, Brazil (1997).

M-J. FALCON Y TELLA, Three-Dimensional Theory of Law, Brill | Nijhoff, (2010).

J. FERRER ARELLANO, Filosofia de las relaciones juridicas, Rialp, Madrid, (1963).

M. FOUCAULT, «Le sujet et le pouvoir », in Dits et Ecrits, p. 306, p. 1041 in Quarto Gallimard, (1982). 
L. FULLER, "Human interaction and the law" in Principles of Social Order: Selected Essays of Lon L. Fuller - Revised Edition (1969).

F. GÉNY, Science et Technique en droit privé positif, TIII, p. 219, Paris, (1914-1924).

G. GOTTLIEB, "Relationism: legal theory for a Relationnal Society", University of Chicago Law Review, vol. 50, p. 567-616, (1983) available online.

D. GOLEMAN, Social Intelligence: The New Science of Human Relationships, Bantam Books, (2007); trans. into French, L’intelligence relationnelle, Robert Laffont, 2009.

W. N. HOHFELD, Fundamental legal conceptions as applied in judicial reasoning and other legal essays, Yale University Press, (1920) available online.

E. JEULAND, Law and Relations, Droit et relation, around J. Nedelsky, (bilingual) co-editor with JF Braunstein, Paris, IRJS, (2018).

E. JEULAND, Théorie relationiste du droit, LGDJ, Paris, (2016).

N. KORKUNOV, Cours de théorie Générale du droit, translation in French Tchernoff, Paris, Girard and Brière, 2nd ed., (1914).

A. LEVI, Teoria generale del diritto, Padova, Cedam, (1953). 
M. NOVAK, Type Theory of Law, An Essay in Psychoanalytic Jurisprudence, Springer, Switzerland, (2016).

G. PAVLAKOS, "Redrawing the Legal Relation", SSRN-id3199276, (2018).

F. C. von SAVIGNY, System des heutigen römischen Recht, 8 tomes (1840-1849), Roman Law System, translation Holloway section 52, Higginbotham (1867).

R. SEVE, Philosophie et théorie du droit, Paris, $2^{\circ}$ éd. Dalloz, nº197 et s., (2017).

L. de SUTTER, Magic, Paris, PUF, (2015).

M. TROPER, Philosophie du droit, Que sais-je ? 3rd ed., Paris, PUF, (2011).

M. TROPER, V. CHAMPEIL-DESPLATS and Ch. GRZEGORCZYK, Théorie des contraintes juridiques, Paris-Bruxelles, Bruylant, LGDJ, (2005).

M. ZIRK-SADOWSKI, «Rapport de Droit», in A-J. Arnaud, Dictionnaire encyclopédique de théorie et de sociologie du droit, Paris, LGDJ (1993, new Ed. 2018). 